\title{
Comparison of various decalcificators in preparation of DNA from human rib bones
}

\author{
Magdalena Żołędziewska, ${ }^{1}$ Stanisław Gronkiewicz, ${ }^{2}$ \\ Tadeusz Dobosz ${ }^{1}$ \\ ${ }^{1}$ Institute of Forensic Medicine, Medical University, ul. Mikulicza- \\ Radeckiego 4, 50-368 Wrocław, Poland \\ ${ }^{2}$ Institute of Anthropology, Polish Academy of Sciences, ul. Kuźnicza 35, \\ 50-951 Wrocław; E-mail: stanislaw.gronkiewicz@antro.pan.wroc.p1
}

\begin{abstract}
Various calcium-binding buffers and agents in DNA preparation from fresh human rib bones were compared. We showed that the buffer described by Kuntze et al. [1996] yielded the highest quantities of DNA, but the obtained DNA was strongly degraded. The best quality DNA was obtained using two buffers: of Hänni et al. [1994] and of Ivanov et al. [1995]. Among the new calcium-binding agents that were not examined before, the most efficient were Bismuth III Oxide and Na/FeEDTA, and - in two-step decalcification - sodium citrate.
\end{abstract}

KEY WORDS DNA preparation, decalcification, DNA degradation

Prz. Antropol. - Anthropol. Rev. (2002), vol. 65, pp. 75-80, Tables 3. ISBN 83-8696980-6, ISSN 0033-2003

\section{Introduction}

DNA preparation from human bones, fresh and, especially, exhumed, usually requires individualized conditions of the isolation process. The same factors, which can protect DNA for hundreds of years, make the isolation process complex and complicated. First, the bone tissue itself is a hard connective tissue with the high content of calcium. Second, after death, during mineralization and protein decay, DNA is bound with hydroxyapatite and forms a compound named bioapatite. For these reasons, decalcification is generally accepted as a necessary step for the effective DNA isolation, although details of the procedure differ: There are methods with and without an additional step of preliminary decalcification, and different concentrations of calcium-chelating agents are used. Most of the widely known methods are based on sodium EDTA (Ethylene Diamino Tetraacetic Acid) as a decalcifier. However, GuSCN (Guanine Isothiocyanate) has been successfully used as well [Höss and PÄÄBO 1993], 
indicating that not only sodium EDTA is effective in the decalcification process. Old exhumed bone samples usually contain inhibitors of the PCR (Polymerase Chain Reaction) reaction. Two-step methods of decalcification generally give better-purified DNA samples [HAMMER 1992]. On the other hand, exhumed bone samples contain only minute amounts of - usually - highly degraded DNA; some decalcifiers can cause further degradation of DNA.

This paper reviews results of DNA preparation from the fresh bone tissue, using sodium EDTA-based buffers described in the literature, as well as quite new, various calcium-chelating agents.

\section{Materials and methods}

Samples of fresh human rib bones from autopsies were cleaned by scalpel scraping and powdered using a singleuse steel hacksaw blade. $100 \mathrm{mg}$ of bone powder was taken for extraction. The powdered bone samples were incubated with the extraction buffers (A through I), according to the references (Table 1); all these buffers $(\mathrm{A}-\mathrm{I})$ contained NaEDTA as the decalcifying agent.

To test different decalcifiers, the powdered bone samples were incubated with water solutions of variety of calcium chelating agents, brought to $\mathrm{pH} 8.0$ by adding sodium hydroxide (see Table 2).

Table 1. Composition of buffers used in this paper

\begin{tabular}{|c|c|}
\hline Composition of the used calcium-chelating buffer & References \\
\hline $\begin{array}{l}\text { Buffer A: } 0.3 \mathrm{M} \text { sodium acetate, } 10 \mathrm{mM} \text { Tris-HCl, } 1 \mathrm{mM} \text { EDTA, } 1 \% \mathrm{SDS} \text {, } \mathrm{pH} 7.8 \text {, } \\
\text { digested }+55^{\circ} \mathrm{C} \text { overnight with proteinase } \mathrm{K} \text { and subsequently prepared with Nucleon } \\
\text { DNA Extraction Kit (Nucleon Scotlab) }\end{array}$ & Kuntze et al. [1996] \\
\hline $\begin{array}{l}\text { Buffer B: 0.5 M EDTA, } 0.1 \% \text { N-laurylsarcosine, } \mathrm{NaOH} \text { to } \mathrm{pH} 8.0 \text {, digested } 18 \mathrm{hr} \text { at } \\
+50^{\circ} \mathrm{C} \text { with proteinase } \mathrm{K}\end{array}$ & Hänni et al. [1994] \\
\hline $\begin{array}{l}\text { Buffer C: } 0.5 \text { M EDTA, } 0.5 \% \text { Tween } 20, \mathrm{NaOH} \text { to } \mathrm{pH} 8.0 \text {, digested overnight at } \\
+37^{\circ} \mathrm{C} \text { with proteinase } \mathrm{K}\end{array}$ & Ivanov et al. [1995] \\
\hline $\begin{array}{l}\text { Buffer D: } 90 \text { mM EDTA, } 45 \mathrm{mM} \text { Tris, } 0.5 \% \text { SDS, } 0.5 \% \text { N-laurylsarcosine, acetic } \\
\text { acid to } \mathrm{pH} 7.8 \text {, digested } 2 \mathrm{hr} \text { at }+55^{\circ} \mathrm{C} \text { with proteinase } \mathrm{K}\end{array}$ & Perry et al. [1989] \\
\hline $\begin{array}{l}\text { Buffer E: } 0.1 \mathrm{M} \text { Tris, } \mathbf{0 . 0 2} \text { M EDTA, } 10 \text { mM guanidine thiocyanate, } 1.3 \% \text { Triton } \\
\text { X100, NaOH to } \mathrm{pH} 8.0 \text {, digested several hours at }+60^{\circ} \mathrm{C} \text { with proteinase } \mathrm{K}\end{array}$ & Höss and Pääbo [1993] \\
\hline $\begin{array}{l}\text { Buffer F: } 100 \mathrm{mM} \mathrm{NaCl}, 40 \mathrm{mM} \text { dithiotreitol, } 10 \mathrm{mM} \text { TRIS, } 10 \mathbf{~ m M ~ N a} \mathbf{2}_{2} \text { EDTA, } \\
2 \% \text { SDS, pH } 8.0 \text {, digested overnight at }+40^{\circ} \mathrm{C} \text { with proteinase } \mathrm{K}\end{array}$ & Fattorini et al. [1989] \\
\hline $\begin{array}{l}\text { Buffer G: } 0.1 \mathrm{M} \text { Tris- } \mathrm{HCl}, 0.1 \mathrm{M} \mathrm{NaCl}, 1 \% \text { Nonidet P40, 0.5\% Na } \mathbf{~ a D T A}_{2} \text { EDH } \mathrm{pH} 7.8 \text {, } \\
\text { digested overnight with proteinase } \mathrm{K}\end{array}$ & Gelsthorpe et al. [1996] \\
\hline $\begin{array}{l}\text { Buffer H: First incubation overnight in } 0.5 \mathrm{M} \mathrm{EDTA} \text { at }+50^{\circ} \mathrm{C} \text {, washed twice } \\
\text { with } 0.9 \% \mathrm{NaCl} \text { and incubated in } 0.1 \mathrm{M} \mathrm{NaCl}, \mathbf{0 . 0 1} \mathrm{M} \mathrm{EDTA}, 0.01 \mathrm{M} \text { Tris- } \mathrm{HCl}, 2 \% \\
\text { SDS, pH } 8.0 \text {, at }+56^{\circ} \mathrm{C} \text { overnight with proteinase } \mathrm{K}\end{array}$ & Hammer et al. [1992] \\
\hline $\begin{array}{l}\text { Buffer I: First incubation } 4-5 \text { days at } 0.5 \text { M EDTA } \mathrm{pH} 7.5 \text { at room temperature; } \\
\text { second incubation in } 0.1 \mathrm{M} \mathrm{NaCl}, \mathbf{0 . 0 1} \text { M EDTA, } 0.01 \mathrm{M} \text { Tris- } \mathrm{HCl}, 40 \mathrm{mM} \\
\text { dithiotreitol, } \mathrm{pH} 8.0 \text {, overnight at }+56^{\circ} \mathrm{C} \text { with proteinase } \mathrm{K}\end{array}$ & Sanz et al. [1996] \\
\hline
\end{tabular}


The decalcification was continued until the bone dust resembled a translucent gel. The time of decalcification depended on the degree of homogenization of the bone powder ( 1 to 5 days). In the one-step procedure the bone powder was directly suspended and incubated with the buffers indicated in Table 2; in the two-step method this was preceded by preliminary decalcification of the bone powder (incubation with $0.5 \mathrm{M}$ NaEDTA $\mathrm{pH} 8.0$ for $48 \mathrm{hrs}$ at room temperature). Buffer $\mathrm{C}$ in the two-step procedure was also used in combinations with different detergents (Table 3 ).

The extracts obtained were purified twice with buffered phenol/chloroform/isoamyl alcohol (25/24/1) and once with chloroform. The quality of the extracted DNA was tested using minigel agarose electrophoresis in $1.5 \% \mathrm{w} / \mathrm{v}$ gel. Electrophoresis was conducted at $10 \mathrm{~V} / \mathrm{cm}$ in TBE (Tris - Boric acid - EDTA). The DNA was stained by ethidium bromide $(1.4 \mu \mathrm{g} / \mathrm{ml}$ buffer/gel). The marker M1 (DNA Gdansk) was used as a migration standard.

For DNA quantification, the Quanti Blot Human DNA Quantitation Kit (Applied Biosystems) was used. The probe included in this kit is complementary to a primate-specific alpha satellite DNA sequence at the locus D17Z1. The test is resistant to high salt concentration in the tested DNA sample.

\section{Results}

Table 2 presents the results of DNA preparation from $100 \mathrm{mg}$ of fresh human rib bone, obtained using various checked isolation protocols and our various DNA calcium-chelating solutions, using onestep and two-step procedures. It shows that the highest yield of DNA was obtained with buffer A [KUNTZE et al. 1996]. On the other hand, using this buffer, as well as buffers $G$ and $H$ [GELSTHORPE et al. 1996 and HAMMER et al. 1992, respectively], we observed a high rate of DNA degradation: the fragments obtained were very short $(<100$ bp). The best quality DNA was obtained using buffers B and C [HANNI et al. 1994 and IVANOV et al. 1995, respectively]: DNA fragments obtained were longer, with most of the fragments between 300 and $1000 \mathrm{bp}$, which is similar to the results reported by FATTORINI et al. [1989].

Among the new decalcifying agents tested in a single-step procedure: $10 \%$ Chelex and saturated solutions of $\mathrm{Na}_{2}$ EDTA, Bismuth III oxide, sodium/ iron EDTA, and potassium EDTA, yielded DNA amounts comparable to those obtained with the pure buffer $\mathrm{C}$ [IVANOV et al. 1995]. The lowest yield was obtained with potassium oxalate. In the two-step process of decalcification, saturated sodium citrate, $\mathrm{Na}_{2}$ EDTA, and potassium EDTA gave the highest yields of DNA (2.5-3 times more than pure buffer C). DNA obtained with sodium/ iron EDTA was strongly degraded, both in one- and two-step preparation procedures. The remaining methods gave DNA fragments, which were longer than $200 \mathrm{bp}$, usually in the range of $0.3-1 \mathrm{~kb}$.

Table 2 also shows that - for all the decalcifiers examined - using the twostep procedures (i.e., adding the step of preliminary incubation with $0.5 \mathrm{M}$ NaEDTA) resulted in the considerable drop in the DNA yield.

The results of using various detergents in bone DNA preparation are presented in Table 3. The highest DNA yield is obtained using SDS, the lowest with CHAPS. 
Table 2. Results of the DNA isolation from $100 \mathrm{mg}$ of human fresh rib bone using calcium-chelating buffers described in Table 1, in one-, or two-step procedure of decalcification. (Each experiment was repeated 4 times, but if results were very different -6 times, and in these cases two extreme results were rejected before calculation of the average values).

\begin{tabular}{|c|c|c|c|c|}
\hline \multirow[t]{2}{*}{$\begin{array}{l}\text { Calcium-chelating buffer or calcium-binding } \\
\text { agent used }\end{array}$} & \multicolumn{2}{|c|}{$\begin{array}{l}\text { One-step procedure (without } \\
\text { preliminary decalcification) } \\
\text { DNA yield }(\mu \mathrm{g})\end{array}$} & \multicolumn{2}{|c|}{$\begin{array}{l}\text { Two-step procedure (with } \\
\text { preliminary decalcification } \\
\text { with } 0.5 \text { M NaEDTA) } \\
\qquad \text { DNA yield }(\mu \mathrm{g})\end{array}$} \\
\hline & Range & Average & Range & Average \\
\hline Buffer A & $83.5-84.5$ & 84.0 & & n.a. \\
\hline Buffer B & $74.9-75.2$ & 75.0 & & n.a. \\
\hline Buffer C & 74.9-75.1 & 75.0 & $5.1-6.0$ & 5.6 \\
\hline Buffer D & $75.0-75.0$ & 75.0 & & n.a. \\
\hline Buffer E & $56.3-77.0$ & 69.3 & & n.a. \\
\hline Buffer F & $37.5-75.0$ & 56.3 & & n.a. \\
\hline Buffer G & $37.5-56.3$ & 46.9 & & n.a. \\
\hline Buffer $\mathrm{H}$ & & n.a. & $37.4-37.6$ & 37.5 \\
\hline Buffer I & & n.a. & $3.8-15.0$ & 7.5 \\
\hline Saturated $\mathrm{Na}_{2}$ EDTA, $\mathrm{NaOH}$ to $\mathrm{pH} 8.0$ & $74.9-75.1$ & 75.0 & $15.2-15.4$ & 15.3 \\
\hline Saturated suspension of Bismuth III oxide & $74.8-75.1$ & 75.0 & $7.4-7.6$ & 7.5 \\
\hline $10 \%$ Chelex 100 & $74.9-75.1$ & 75.0 & $11.0-11.4$ & 11.3 \\
\hline Saturated Sodium and Iron EDTA pH 8.0 & $75.0-75.0$ & 75.0 & $9.3-9.5$ & 9.4 \\
\hline Saturated Potassium EDTA pH 8.0 & $62.4-62.6$ & 62.5 & $11.3-18.8$ & 15.6 \\
\hline Saturated Ammonium EDTA pH 8.0 & $37.5-37.5$ & 37.5 & $7.7-7.9$ & 7.8 \\
\hline Saturated Lithium EDTA pH 8.0 & $37.5-37.5$ & 37.5 & $11.3-11.3$ & 11.3 \\
\hline Saturated Cesium EDTA pH 8.0 & $18.8-37.5$ & 28.1 & $5.5-5.7$ & 5.6 \\
\hline Saturated Sodium citrate $\mathrm{pH} 8.0$ & $18.6-18.8$ & 18.7 & $18.8-18.8$ & 18.8 \\
\hline Saturated Calgon & $18.8-18.8$ & 18.7 & $7.5-7.6$ & 7.5 \\
\hline Saturated Sodium Methylene Phosphonate $\mathrm{pH} 8.0$ & $18.6-18.9$ & 18.7 & $1.7-2.0$ & 1.9 \\
\hline Saturated Potassium oxalate $\mathrm{pH} 8.0$ & $5.0-7.5$ & 7.0 & $7.5-7.6$ & 7.5 \\
\hline
\end{tabular}

n.a. - not applicable.

Saturated solutions were prepared using deionized water $18 \mathrm{M} \Omega$; they also contained $0.5 \%$ Tween 20 and proteinaze K; extracts were digested overnight at $+37^{\circ} \mathrm{C}$.

Calgon - the popular household powder for washing machines, manufactured by Benckisher.

Table 3. Effect of using various detergents during two-step DNA preparation* from $100 \mathrm{mg}$ of fresh human rib bone

\begin{tabular}{lc}
\hline Detergent $(0.5 \%)$ & Average DNA yield $(\mu \mathrm{g})$ \\
\hline SDS & 13.1 \\
Triton X-100 & 8.4 \\
Nonidet P.-40 & 8.4 \\
N-laurylosarcosine & 8.4 \\
Tween 20 & 5.6 \\
CHAPS & 3.8 \\
\hline
\end{tabular}

* First step - incubation in 0.5M sodium EDTA, second step - incubation in buffer $\mathrm{C}$ with various detergents. $S D S$ - sodium dodecyl sulfate

CHAPS - 3-[(3-Cholamidopropyl)dimethylammonio]-1propane-sulfonate

\section{Discussion}

Many authors have described various methods of DNA preparation from bones, but it is widely accepted that the problem is as yet unresolved. We think a suitable method of bone decalcification is essential for effective purification of DNA from bone tissue. For this reason we focused only on this first step of DNA isolation from bones.

Most authors used sodium EDTA as chelating agent in decalcification procedures. We showed that other decalcifiers 
are suitable as well. We obtained good results with bismuth III oxide, chelex 100, potassium EDTA and other EDTA salts.

Generally, one-step methods (without preliminary decalcification) gave higher DNA yield than the corresponding twostep methods; the only exception was with potassium oxalate, where the yield in one-step method was already very low (in the range obtained in the 2-step procedures). Preliminary decalcification of the bone powder (two-step procedure) compromises the yield of DNA, but it may be useful for preliminary cleaning of the bone surface (EDTA chelates soil iron ions, which may inhibit PCR reaction) and, for this reason, should be applied when high DNA preservation in bone samples is expected. For severely damaged bones, the methods without preliminary decalcification seem more suitable, because of the smaller loss of DNA during preparation.

Generally, one-step methods (without preliminary decalcification) gave higher DNA yield than the corresponding two-step methods; the only exception was with potassium oxalate, where the yield in one-step method was already very low (in the range obtained in the 2-step procedures). Since preliminary decalcification of the bone powder (twostep procedure) compromises the yield of DNA, it may apply only when a high DNA preservation in fresh bone samples is expected. For severely damaged bones, the methods without preliminary decalcification are better, because of smaller loss of the DNA during preparation. The yield of DNA in the bone DNA preparation may also depend on the detergent used in the extraction buffer.
It is important to choose an adequate technique of DNA quantification. The spectrophotometric method from time to time failed to yield reliable data (for example when using iron EDTA), and in these cases, the QuantiBlot Test is better. In very old bones, DNA is complexed with bioapatite, and the longer time of decalcification in these cases is necessary.

The rib bones are significantly less valuable for anthropologists, and for this reason we chose these bones as our main object for DNA preparation when we started our study. On the other hand, for DNA preparation we need a big fragment of the bone, because the DNA preparation is preceded by mechanically removing the dirty and decomposed bone surface. Unfortunately, we realized later that rib bones from authentic exhumation cases were almost always seriously damaged, and selection of a big fragment was difficult. If the bone fragment is too small, handling and purification are technically difficult.

\section{Acknowledgments}

This paper benefited from the criticism, valuable comments and advice of an anonymous referee, whom we thank very much.

\section{References}

Fattorini F., S. Caccio, S. Gustincich, B. AltaMURA, G. GRAZIOSI, 1989, Sex determination from skeleton. A new method using a DNA probe, Acta Med. Leg. Soc., 39, 201-205

GELSTHORPE A., K. GELSHORPE, R. SOKOL, 1996, Extraction of DNA using monoclonal anti-DNA and magnetic beads, BioTechniques, 22, 1082

Hammer U., U. Bulnheim, R. Wegener, 1992, On DNA typing of hard tissue, Adv. Forens. Haemogen., 4, 213-215 
HÄNNI C., V. LAUdeT, D. STEHElin, P. TABERLET, 1994, Tracking the origins of the cave bear (Ursus Spelaeus) by mitochondrial DNA sequencing, Proc. Natl. Acad. Sci. USA, 91, 12336-40

HösS M., S. РÄÄBO, 1993, DNA extraction from Pleistocene bones by a silica-based purification method, Nucleic Acid Res., 21, 3913-14

Ivanov P., P. Gill, K. Sullivan, C. Kimpton, R. Piercy, N. Benson, G. Tully, I. Evett, A. MANNUCCI, 1995, DNA testing of bone material as a means of establishing the authenticity of the putative remains of tsar Nicolas II, Adv. Forens. Sci., 6, 156-166
KuntZE K., W. HucKenBecK, W. Bonte, K. ALt, 1996, Sex determination in ancient bones, Adv. Forens. Haemogen., 6, 298-300

PERRY W.L.III., B.A.WILliaM, M. BASS, 1989, The autodegradation of deoxyribonucleic acid (DNA) in human rib bone and its relationship to the time interval since death, J. For. Sci., 29, 144-153

SAnz P., V. PRIETO, M. ANDREs, 1996, PCR genotyping in dental pulp from old human skeletal remains and fire victims, Adv. Forens. Haemogen., 6, 319-321

\section{Streszczenie}

W pracy podano przegląd technik preparacji DNA z kości ludzkich (fragmentów żeber pobranych wkrótce po śmierci) ze szczególnym uwzględnieniem etapu jedno- i dwustopniowego odwapniania tkanki kostnej przed wydobyciem z niej materiału genetycznego (Tabela 2). Wypróbowano bufory odwapniające stosowane przez różnych autorów (Tabela 1) a także odwapniacze własnego pomysłu. Stwierdzono, że ze $100 \mathrm{mg}$ wyżej wymienionego materiału można uzyskać ponad 80 mikrogramów DNA, jednakże długość wypreparowanych fragmentów nie przekracza $1000 \mathrm{bp}$. Najlepszym odwapniaczem okazał się $0.5 \mathrm{M}$ roztwór EDTA. Wypróbowano (Tabela 3) także przydatność różnych detergentów, wspomagających działanie odwapniaczy. Najlepsze wyniki osiagnięto przy użyciu soli sodowej siarczanu dodecylu (SDS). 